\title{
PENGARUH EDUKASI PERSALINAN VIA WHATSAPP GROUP TERHADAP PENGETAHUAN IBU HAMIL MENGHADAPI PERSALINAN DI KABUPATEN PRINGSEWU
}

\section{THE EFFECT OF DELIVERY EDUCATION VIA WHATSAPP GROUP ON KNOWLEDGE OF PREGNANT MOTHERS FACING DELIVERY IN PRINGSEWU DISTRICT}

\author{
Apri Sulistianingsih $^{1}$, Dzul Istiqomah Hasyim ${ }^{2}$ \\ ${ }^{1}$ Fakultas Kesehatan, Universitas Muhammadiyah Pringsewu \\ ${ }^{2}$ Fakultas Kesehatan, Universitas Muhammadiyah Pringsewu \\ Email Correspondence: sulistianingsih.apri@gmail.com
}

\begin{abstract}
The Effect Of Delivery Education Via Whatsapp Group On Knowledge Of Pregnant Mothers Facing Delivery In Pringsewu District Social distancing policies prevent people from traveling except for emergency purposes. The use of WhatsApp as a group container is because currently WhatsApp is the most widely used messaging medium. The purpose of this study was to determine the Effect of Childbirth Education Via Whatsapp Group on Knowledge of Pregnant Women Facing Childbirth in Pringsewu Regency. This study uses a quantitative method with a quasi-experimental type of research in the form of a pre-post test design. The population of this study were all pregnant women who met the inclusion criteria and were willing to participate in the study by signing the Consent After Explanation (PSP) sheet. The number of samples consisted of 30 control groups and 30 treatment groups with inclusion criteria of pregnant women who have smart phones in Pringsewu Regency. Data analysis used chi square test and independent $T$ test. The results showed that there were differences in knowledge of pregnant women facing childbirth before and after the study, both in the control and treatment groups (P value <0.05). The results also showed that the average value of the increase in knowledge scores of pregnant women facing childbirth in the intervention group was greater than the control group. The average increase in knowledge of pregnant women facing childbirth in the control and treatment groups there was a significant difference ( $p$ value <0.05)
\end{abstract}

Keywords: Education, Childbirth, Knowledge, Whatsapp group

\begin{abstract}
Abstrak: Pengaruh Edukasi Persalinan Via Whatsapp Group Terhadap Pengetahuan Ibu Hamil Menghadapi Persalinan Di Kabupaten Pringsewu. Kebijakan social distancing membuat masyarakat tidak bepergian kecuali untuk keperluan darurat. Penggunaan whatsapp sebagai wadah group dikarenakan saat ini whasapp sebagai media berkirim pesan yang paling banyak digunakan. Tujuan penelitian ini adalah untuk mengetahui Pengaruh Edukasi Persalinan Via Whatsapp Group Terhadap Pengetahuan Ibu Hamil Menghadapi Persalinan Di Kabupaten Pringsewu. Penelitian ini menggunakan metode kuantitatif dengan jenis penelitian Quasy experiment yang berbentuk pre-post test design. Populasi penelitian ini seluruh ibu hamil yang memenuhi kriteria inklusi dan bersedia mengikuti penelitian dengan menandatangani lembar Persetujuan Setelah Penjelasan (PSP). Jumlah sampel terdiri dari 30 kelompok kontrol dan 30 kelompok perlakuan dengan kriteria inklusi ibu hamil yang memiliki smart phone yang berada di Kabupaten Pringsewu. Analisis data menggunakan uji chi square dan T test independen. Hasil penelitian didapatkan perbedaan pengetahuan ibu hamil menghadapi persalinan sebelum dan sesudah penelitian baik pada kelompok kontrol maupun perlakuan ( $\mathrm{P}$ value $<0,05$ ). Hasil juga menunjukkan bahwa nilai rata-rata peningkatan skor pengetahuan ibu hamil menghadapi persalinan pada kelompok intervensi lebih besar dibandingkan dengan kelompol kontrol. Rata-rata peningkatan pengetahuan ibu hamil menghadapi persalinan pada kelompok kontrol dan perlakuan terdapat perbedaan yang signifikan $(\mathrm{p}$ value $<0,05$ )
\end{abstract}

Kata Kunci: Edukasi, Persalinan, Pengetahuan, Whatsapp group 


\section{PENDAHULUAN}

Pendidikan kesehatan pada ibu hamil sangat penting untuk kesehatan ibu dan janin selama kehamilan sampai menjelang persalinan. Saat ini, wanita hamil memperoleh sebagian besar informasi mereka menerima tentang kelahiran dari media elektronik, buku, atau teman dan keluarga, bukan penyedia layanan kesehatan atau pendidik persalinan. Namun demikian, banyak perempuan tidak mengakses layanan kesehatan primer dan strategi promosi kesehatan tertentu sangat penting bagi janin kesehatan. Oleh karena itu, pendidikan kesehatan selama kehamilan dianggap sebagai salah satu periode paling tepat untuk ditangani topik pendidikan kesehatan dalam mempersiapkan persalinan.(King et al., 2019)

Di Indonesia pendidikan kesehatan biasanya dilakukan dalam kelas ibu hamil. Kelas ibu hamil merupakan sarana untuk belajar bersama tentang kesehatan bagi ibu hamil, dalam bentuk tatap muka dalam kelompok yang bertujuan untuk meningkatkan pengetahuan dan ketrampilan ibu-ibu mengenai kehamilan, persalinan, perawatan nifas, perawatan bayi baru lahir, mitos dan penyakit menular (Lucia et al., 2013) (Saputri, 2018) . Pandemi covid 19 memberikan dampak terhadap tatanan kehidupan sosial dan masyarakat. Indonesia tidak lepas dari COVID-19, dengan data kasus positif per 09 Oktober 2020 sebanyak 321.000 jiwa, sembuh 244.000 jiwa, dan meninggal sebanyak 11.580 jiwa. (Kemenkes RI., 2020) Kebijakan social distancing membuat masyarakat tidak bepergian kecuali untuk keperluan darurat.(Sutrisna, 2020)

Kehamilan pada masa pandemic Covid 19 dapat meningkatkan risiko morbiditas sampai mortalitas. Hal ini dikarenakan system imunitas wanita hamil mengalami perubahan dan lebih rentan terhadap virus terutama covid 19. Ibu hamil juga mengalami peningkatan kecemasan dan kehawatiran pada saat akan datang ke tenaga kesehatan untuk mendapatkan pelayanan kehamilan.(Liu et al., 2020) Hal ini ditambah lagi kelas ibu hamil ditiadakan sampai waktu yang belum ditentukan.(KEMENKES, 2020) Akibatnya ibu hamil menggunakan alternatif lain untuk mendapatkan informasi kesehatan tentang kehamilan contohnya adalah penggunaan internet. Perkembangan teknologi mengalami peningkatan yang sangat pesat terutama akses internet. Pengguna internet berdasarkan level ekonomi paling banyak pada tingkat ekonomi menengah 74,62\%.(APJII, 2017) Penggunaan smart phone di Indonesia telah mencapai seluruh pelosok negeri. Saat ini akses penggunaan e-health di Negara berkembang menunjukkan perubahan yang signifikan. e-health dapat menggunakan smartphone untuk mengambil data pasien, monitoring, keputusan klinis, pendidikan kesehatan dan penelitian.(Blaya et al., 2010)

Munculnya smartphone, tablet dan aplikasi seluler merupakan perkembangan penting dalam kesehatan dan perawatan kesehatan, terutama aplikasi sosial yang memberikan kesempatan belajar dan kolaborasi tenaga kesehatan yang sibuk dan dukungan peer-to-peer dan pendidikan kesehatan untuk masyarakat umum. Penggunaan smartphone efektif untuk komunikasi tenaga kesehatan dan pasien di abad ke-21. Tren media sosial terbaru mengarah ke layanan jejaring sosial dan alat seluler, seperti Instagram dan WhatsApp, sebagai media yang layak untuk berbagi dan mendiskusikan kasus klinis dan medis dan pengetahuan kesehatan.(Boulos et al., 2016)

Penelitian sebelumnya tentang penggunaan aplikasi Kartu Menuju Sehat (KMS Mobile) lebih murah karena tidak memerlukan biaya cetak, mudah diakses dimanapun dan kapanpun oleh pengguna. Aplikasi ini memiliki fitur grafik informasi kesehatan ibu dan anak. Hasil uji validasi dan kepuasan pengguna menunjukkan hampir semua subjek penelitian menerima system ini. (Muktashim, 2018) Namun demikian system ini masih berupa bagian dari buku KIA yang hanya berisi informasi tentang KMS belum mencakup seluruh bagian buku KIA. selain itu kelemahan aplikasi kesehatan umumnya adalah peserta harus membuka aplikasi dan terkadang system yang lama membuat aplikasi lama dibuka, selain itu penggunaan aplikasi Mhealth tidak bisa melakukan diskusi secara langsung dibandingkan dengan penggunaan grup social media.

Hasil survey menggunakan google form pada 15 orang ibu hamil di Kabupaten Pringsewu didapatkan ibu hamil, 70\% ibu hamil belum siap dalam menghadapi persalinan karena tidak memiliki pengetahuan yang cukup tentang kebutuhan persalinan. Sebanyak $75 \%$ ibu hamil mengakses informasi kesehatan ibu hamil melalui social media dan internet. Sebanyak $60 \%$ ibu hamil tidak yakin informasi 
yang diberikan di internet adalah benar. Sebanyak 100\% ibu hamil menginginkan forum diskusi persiapan persalinan yang mudah di akses.

Sampai saat ini penggunaan whatsapp group masih belum diteliti dalam pendidikan kesehatan kebidanan. Hal ini dapat menjadi alternative di masa pandemic Covid 19. Ibu hamil dapat memperoleh pengetahuan dalam menghadapi persalinan, sehingga ibu lebih siap menjalani persalinannya. Grup WhatsApp dipilih sebagai alat pendukung, mengingat banyaknya variasi kelompok yang biasanya dilatih dari jarak jauh. Hasil analisis menunjukkan pengguna grup WhatsApp sebagai social, grup WhatsApp menghasilkan partisipasi yang lebih tinggi daripada kebanyakan media sosial lainnya, Menyebarkan motif penggunaan media social, Kemungkinan karena dengan atribut 'kehadiran' dan 'keterlibatan' WhatsApp yang relatif tinggi, Berkontribusi pada perilaku sehat dan advokasi kesehatan. (Simons, 2018)

Media diskusi dan edukasi yang dapat diberikan melalui social media yang benar dapat memberikan informasi persiapan persalinan pada ibu hamil dan meningkatkan pengetahuan persiapan persalinandi era pandemic ini. Dalam system grup juga dapat membuat antara ibu hamil saling berdiskusi dan segera mendapatkan jawaban dari setiap pertanyaan dari peneliti.(Covid- et al., 2020)

Berdasarkan uraian latar belakang diatas tentang perkembangan era digital yang seluruhnya membutuhkan akses informasi cepat dan tepat. Peneliti tertarik mengembangkan whatapp dapat membentuk grup ibu hamil yang didalamnya dapat berdiskusi tentang persiapan persalinan melalui sharing informasi, foto dan video selama masa pandemic covid 19 untuk meningkatkan pengetahuan ibu tentang persiapan persalinan. Penggunaan whatsapp sebagai wadah group dikarenakan saat ini whasapp sebagai media berkirim pesan yang paling banyak digunakan. Kemudahan penggunaan media social dalam grup juga dapat mengurangi cost yang banyak. Ibu hamil mendapatkan informasi kesehatan tanpa perlu berisiko harus ke tenaga kesehatan. Didalam grup whatsapp dapat mengirimkan gambar, suara dan sharing video sehingga ibu bisa berdiskusi tentang perawatan kehamilannya.Berdasarkan latar belakang diatas maka peneliti mengangkat tema "Pengaruh Edukasi Persalinan Via Whatsapp Group Terhadap Pengetahuan Ibu Menghadapi Persalinan Di Kabupaten Pringsewu"

\section{METODE}

Penelitian ini menggunakan metode kuantitatif dengan jenis penelitian Perlakuan Semu (Quasy experiment) yang berbentuk pre-post test design. Subjek dibagi menjadi 2 kelompok yaitu kelompok kontrol dan kelompok perlakuan. (Creswell, 2016). Variabel bebas dalam peneliian ini adalah Edukasi Persalinan Via Whatsapp Group. Variabel terikat pada penelitian ini adalah Pengetahuan Ibu Hamil Menghadapi Persalinan. Subjek pada penelitian ini adalah seluruh ibu hamil yang memenuhi kriteria inklusi dan bersedia mengikuti penelitian dengan menandatangani lembar Persetujuan Setelah Penjelasan (PSP). Kriteria Inklusi pada penelitian ini adalah : Ibu Hamil Trimester II dan III dalam kondisi normal, Ibu hamil yang memiliki smart phone yang berada di Kabupaten Pringsewu dan Bersedia jadi responden. Kriteria eksklusi adalah Ibu dengan kehamilan tidak diinginkan. Pada kelompok intervensi Edukasi Persalinan Via Whatsapp Group ibu hamil yang digunakan dalam sebagai media informasi yang dapat di akses pada masa pandemic covid 19 yang berprinsip pada peningkatan Ibu Hamil Menghadapi Persalinan. Edukasi Persalinan Via Whatsapp Group pada ibu hamil ini memfasilitasi ibu hamil mendapatkan informasi tentang persiapan persalinan secara online. Setelah Edukasi Persalinan Via Whatsapp Group pada ibu hamil diberikan, peneliti mengukur peningkatan pengetahuan ibu hamil tentang pengetahuan ibu menghadapi persalinan. Perlakuan diberikan selama empat minggu. Pada kelompok control Metode pendidikan kesehatan yang digunakan pada kelompok kontrol adalah metode pemberian pendidikan standar yang dilakukan oleh bidan di PMB berdasarkan pedoman buku KIA. Pendidikan diberikan 30-40 menit pada pertemuan 


\section{Vol 10 No 2 Juli 2021 | Page 85-94}

pertama dan pada pertemuan selanjutnya dievaluasi peningkatan pengetahuan tentang perawatan menghadapi persalinan. Evaluasi digunakan untuk menilai pengaruh Edukasi Persalinan Via Whatsapp Group Terhadap Pengetahuan Ibu Hamil Menghadapi Persalinan Di Kabupaten Pringsewu. Evaluasi dilakukan setelah materi selesai. Evaluasi yang dilakukan meliputi pengetahuan ibu hamil tentang persiapan persalinan pada masa pandemic covid 19. Analisa Bivariat dengan uji statistik yang akan digunakan pada penelitian ini untuk Pengaruh Edukasi Persalinan Via Whatsapp Group Terhadap Pengetahuan Ibu Hamil Menghadapi Persalinan Di Kabupaten Pringsewu dengan menggunakan $\mathrm{T}$ test.

\section{HASIL}

1. Pengetahuan Ibu Hamil Menghadapi Persalinan pada kelompok kontrol dan perlakuan sebelum penelitian

Tabel 1 Pengetahuan Ibu Hamil Menghadapi Persalinan pada kelompok kontrol dan perlakuan sebelum penelitian

\begin{tabular}{lcllll}
\hline Pengetahuan & Mean (SD) & Rentang & $\begin{array}{l}\text { Mean } \\
\text { Diff }\end{array}$ & P value & T (CI 95\%) \\
\hline $\begin{array}{l}\text { Intervensi } \\
\text { Kontrol }\end{array}$ & $34,27(9,60)$ & $16-60$ & 3,600 & 0,112 & $1,615(-0861-8,061)$ \\
\hline
\end{tabular}

Keterangan uji: *) T Independent test

Berdasarkan tabel 1 didapatkan Pengetahuan Ibu Hamil Menghadapi Persalinan sebelum penelitian.. Pengetahuan Ibu Hamil Menghadapi Persalinan pada kelompok kontrol sebelum penelitian adalah 30,67 (7,52). pengetahuan ibu hamil menghadapi persalinan pada kelompok intervensi sebelum penelitian adalah $34,27(9,60)$. Hasil uji statistik tidak ada perbedaan pengetahuan ibu hamil menghadapi persalinan pada kelompok kontrol maupun kelompok perlakuan sebelum penelitian ( $\mathrm{p}$ value 0,112 ).

2. Pengetahuan Ibu Hamil Menghadapi Persalinan di kelompok kontrol dan perlakuan setelah penelitian

Tabel 2 Pengetahuan Ibu Hamil Menghadapi Persalinan di kelompok kontrol dan perlakuan setelah penelitian

\begin{tabular}{lcclll}
\hline Pengetahuan & Mean (SD) & Rentang & $\begin{array}{l}\text { Mean } \\
\text { Diff }\end{array}$ & P value & T (CI 95\%) \\
\hline Intervensi & $79,47(9,95)$ & $56-100$ & 26,667 & 0,000 & $10,886(21,763-31,570)$ \\
Kontrol & $52,80(9,00)$ & $36-72$ & & & \\
\hline \multicolumn{2}{c}{ Keterangan uji: $\left.{ }^{*}\right)$ T Independent test } & & &
\end{tabular}

Berdasarkan tabel 2 didapatkan Pengetahuan Ibu Hamil Menghadapi Persalinan setelah penelitian.. Pengetahuan Ibu Hamil Menghadapi Persalinan pada kelompok kontrol setelah penelitian adalah 52,80 $(9,00)$. pengetahuan ibu hamil menghadapi persalinan pada kelompok intervensi sebelum penelitian adalah 79,47(9,95). Hasil uji statistik ada perbedaan pengetahuan ibu hamil 
Vol 10 No 2 Juli 2021 | Page 85-94

menghadapi persalinan pada kelompok kontrol maupun kelompok perlakuan sebelum penelitian ( $\mathrm{p}$ value 0,000$)$

3. Pengaruh Edukasi Persalinan Via Whatsapp Group Terhadap Pengetahuan Ibu Hamil Menghadapi Persalinan Di Kabupaten Pringsewu

Tabel 3 Pengaruh Edukasi Persalinan Via Whatsapp Group Terhadap Pengetahuan Ibu Hamil Menghadapi Persalinan Di Kabupaten Pringsewu

\begin{tabular}{lllllll}
\hline Pengetahuan & Intervensi & \multicolumn{3}{l}{ Kontrol } & & P value \\
& & & value & & \\
\hline & pre & post & & pre & post & \\
\hline Mean(SD) & $34,27(9,60)$ & $79,47(9,95)$ & 0,000 & $30,67(7,52)$ & $52,80(9,00)$ & 0,000 \\
Delta & & & & & & \\
Mean (SD) & $45,20(15,58)$ & & & $22,13(8,25)$ & & 0,000 \\
& & & & & & \\
\end{tabular}

Keterangan uji: *) T Paired Test **) T Independent Test

Berdasarkan tabel 3 didapatkan perbedaan pengetahuan ibu hamil menghadapi persalinan sebelum dan sesudah penelitian baik pada kelompok kontrol maupun perlakuan ( $\mathrm{P}$ value $<0,05$ ). Hasil juga menunjukkan bahwa nilai rata-rata peningkatan skor pengetahuan ibu hamil menghadapi persalinan pada kelompok intervensi lebih besar dibandingkan dengan kelompol kontrol. Rata-rata peningkatan pengetahuan ibu hamil menghadapi persalinan pada kelompok kontrol dan perlakuan terdapat perbedaan yang signifikan $(\mathrm{p}$ value $<0,05$ ).

\section{PEMBAHASAN}

1. Pengetahuan Ibu Hamil Menghadapi Persalinan pada kelompok kontrol dan perlakuan sebelum penelitian

Pada penelitian ini pengetahuan ibu hamil menghadapi persalinan pada kelompok kontrol sebelum penelitian adalah 30,67 $(7,52)$ lebih rendah dibandingkan dengan kelompok intervensi sebelum penelitian adalah 34,27 (9,60). Namun demikian tidak ada perbedaan bermakna pengetahuan ibu hamil menghadapi persalinan pada kelompok kontrol maupun kelompok intervensi sebelum penelitian ( $\mathrm{p}$ value 0,112 ).

Pengetahuan merupakan hasil tahu seseorang terhadap objek melalui indra yang dimilikinya. (Notoatmodjo, 2015) Persiapan persalinan merupakan persipan untuk mengeluarkan hasil konsepsi yang telah cukup bulan atau dapat hidup di luar kandungan melalui jalan lahir atau melalui jalan lain, dengan bantuan atau tanpa bantuan (Sulistyawati \& Nugraheny, 2013). Oleh karena itu pengetahuan ibu hamil menghadapi persalinan merupakan hasil tau dari pengindraan ibu hamil untuk mengetahui tentang persiapan yang dibutuhkan menjelang persalinan untuk mengeluarkan hasil konsepsi.

Kondisi kehamilan menyebabkan penurunan kekebalan parsial karena perubahan fisiologi pada saat kehamilan, sehingga mengakibatkan ibu hamil lebih rentan terhadap infeksi virus. Oleh karena itu, pandemi COVID-19 sangat mungkin menyebabkan konsekuensi yang serius bagi ibu hamil. Langkah-langkah social distancing telah terbukti efektif dalam mengurangi penularan penyakit. Termasuk hal ini juga berlaku pada ibu hamil, agar membatasi diri untuk tidak banyak terpapar dengan lingkungan luar, apalagi melakukan perjalanan ke daerah pandemi. Risiko ibu 
hamil bisa tertular COVID-19 salah satunya saat melakukan kunjungan pemeriksaan kehamilan di klinik kebidanan atau rumah sakit. Sehingga ibu hamil harus lebih meningkatkan kewaspadaan dengan terus disiplin dalam penggunaan APD. Ibu hamil bisa membatasi kunjungan ke klinik kebidanan atau rumah sakit dengan melakukan konsultasi via daring, aktif melakukan pengecekan sendiri tanda dan bahaya saat kehamilan, dan hanya melakukan kunjungan saat ditemukan hal-hal yang mengkhawatirkan .

Materi pengetahuan tentang persiapan menjelang persalinan biasanya diberikan oleh tenaga kesehatan khususnya bidan pada saat kunjungan antenatal dan kehadiran kelas ibu hamil. Pada masa Pandemi Covid 19 kegiatan kelas hamil ada tahun 2020 mengalami masa vakum. Hal ini membuat ibu mengalami kesulitan untuk mengakses informasi yang benar tentang persiapan persalinan.

Hal ini sesuai dengan penelitian yang Hutagaol et al., (2021) yang menyatakan bahwa pelayanan maternal dan neonatal tidak luput dari dampak dari pandemi covid. Hasil analisis statistic menunjukkan ada penurunan pada kunjungan kehamilan trimester 2 dan pada kunjungan kehamilan trimester 3. Dengan demikian responden yang terdampak pandemi secara ekonomi lebih cenderung tidak melakukan kunjungan kehamilan dibandingkan dengan yang tidak terdampak pandemi secara ekonomi. Dari hasil penelitian ada hubungan antara dampak pandemi covid 19 dengan kepatuhan ibu melaksanakan kunjungan kehamilan selama pandemi, hal ini disebabkan karena kebijakan dari pemerintah untuk melakukan pembatasan dan juga kecemasan ibu hamil jika tertular covid 19.

Dampak dari rendahnya kunjungan antenatal care pada masa pandemic covid 19 adalah rendahnya pengetahuan ibu hamil dalam pencegahan covid 19 dan persiapan persalinan. Hal ini sesuai dengan penelitian yang menyatakan bahwa pengetahuan kelompok kontrol 30,67 $(7,52)$ lebih rendah dibandingkan dengan kelompok intervensi sebelum penelitian adalah $34,27(9,60)$ yang termasuk dalam kategori pengetahuan rendah.(Arikunto, 2010)

Hal ini didukung oleh kajian literature Hinonaung et al., (2020) yang menyatakan bahwa Akibat dari pandemi ini terjadi pembatasan aktivitas, termasuk layanan kesehatan pada ibu hamil. Ibu hamil menjadi takut pergi ke fasilitas kesehatan karena takut tertular. Hal ini menyebabkan kunjungan ibu hamil di pelayanan kesehatan terjadi penurunan. sosial distancing mengakibatkan terjadinya perubahan yang tidak menentu, baik itu secara fisiologi maupun psikologi, sehingga dibutuhkan cara khusus dalam memenuhi kebutuhan ibu hamil tersebut. Pengetahuan ibu hamil tentang infeksi COVID-19 dan oersiapan persalinan masih kurang. Hal ini disebabkan ketidakmampuan ibu hamil dalam memahami COVID-19 serta pencegahannya. Perlu adanya pendidikan kesehatan bagi ibu hamil secara berulang kali sehingga ibu hamil semakin meningkat pengetahuannya dalam menjalani kehamilan dan mempersiapkan kehamilan pada masa pandemic covid 19.

2. Pengetahuan Ibu Hamil Menghadapi Persalinan di kelompok kontrol dan perlakuan setelah penelitian

Pada penelitian ini pengetahuan ibu hamil menghadapi persalinan setelah penelitian pada kelompok kontrol lebih rendah setelah penelitian 52,80 $(9,00)$ dibandingkan kelompok intervensi 79,47(9,95). Didukung hasil uji statistik ada perbedaan pengetahuan ibu hamil menghadapi persalinan pada kelompok kontrol maupun kelompok perlakuan sebelum penelitian ( $p$ value 0,000 .

Whatsapp merupakan aplikasi percakapan gratis yang terintegrasi dengan android dan website.(Gon et al., 2017) Salah satu fitur dari whatsapp adalah whatsapp group. Pada fitur whatsapp group membuat setiap penggunanya tetap terhubung dengan orang-orang yang penting bagi anda, keluarga, dan rekan kerja dengan chat group. Dengan group anda dapat membagikan pesan, foto, dan video hingga 256 orang sekaligus. Anda juga dapat memberi nama group, membisukan, atau menyesuaikan pemberitahuan dan masih banyak lagi (Boulos et al., 2016).

Di era digital seperti saat ini banyak informasi bisa didapatkan. Mulai informasi yang diperoleh dari hasil pencarian di mesin Google, dari media sosial seperti Facebook, Instagram 
dari akun-akun tertentu yang memberikan informasi yang diinginkan oleh ibu dan ayah sebagai orang tua baru, atau mengikuti grup-grup yang diikuti, baik grup yang ada di Facebook maupun grup yang ada di aplikasi perpesanan seperti Whatsapp. Whatsapp Group (WAG) yang digunakan oleh ibu-ibu sebagai wadah untuk berdiskusi sebagai sesama orang tua baru. Tema yang sering jadi pembahasan adalah seputar kesehatan ibu dan anak, imunisasi, saran dan dukungan dari semua anggota, KB, ASI, biaya persalinan, dan pola asuh (Wenerda, 2019).

Penelitian ini sejalan dengan Irawati et al., (2019) bahwa penyuluhan kesehatan tentang mempersiapkan kehamilan dan persalinan ditengah pandemic Covid-19 dan konsultasi melalui WhatsApp group. Hasil kegiatan ini adalah Para Ibu Hamil dapat mempersiapkan kehamilan dan persalinan dengan tenang dan tetap focus walau di tengah masa pandemic covid 19. Diperlukan pemahaman bagi para ibu yang sedang menjalani masa kehamilan dan mempersiapkan persalnan saat ini. Pentingnya peran bidan sebagai tenaga kesehatan untuk memberikan pendidikan kesehatan secara virtual (online). Sehubungan dengan pembatasan kegiatan keluar rumah. Implikasi dari kegiatan ini menambah pengetahuan dan solusi bagi para ibu hamil yang mempersiapkan kehamilan dan masa persalinan ditengah pandemic Covid - 19 .

3. Pengaruh Edukasi Persalinan Via Whatsapp Group Terhadap Pengetahuan Ibu Hamil Menghadapi Persalinan Di Kabupaten Pringsewu

Pada penelitian ini ada perbedaan pengetahuan ibu hamil menghadapi persalinan sebelum dan sesudah penelitian baik pada kelompok kontrol maupun perlakuan ( $\mathrm{P}$ value $<0,05$ ). Hasil juga menunjukkan bahwa nilai rata-rata peningkatan skor pengetahuan ibu hamil menghadapi persalinan pada kelompok intervensi lebih besar dibandingkan dengan kelompol kontrol. Ratarata peningkatan pengetahuan ibu hamil menghadapi persalinan pada kelompok kontrol dan perlakuan terdapat perbedaan yang signifikan ( $\mathrm{p}$ value $<0,05$ ).

Ibu hamil pada masa pandemic covid 19 sangat berisiko untuk tertular. Wanita hamil menjadi kelompok yang rentan terhadap patogen penyebab penyakit pernafasan dan pneumonia. Hal ini dapat terjadi karena saat hamil, wanita hamil berada pada keadaan imunosupresif dan mengalami perubahan fisiologis kehamilan, seperti peningkatan diafragma, peningkatan konsumsi oksigen, dan edema mukosa saluran pernafasan yang dapat membuat rentan terhadap hipoksia. Selain itu, imunitas ibu hamil yang menurun dapat menyebabkan peningkatan kerentanan terhadap infeksi penyakit (Chahya Kharin et al., 2020).

Persiapan persalinan bertujuan untuk menyiapkan semua kebutuhan secara fisik, psikologis dan finansial selama kehamilan maupun proses persalinan. Persiapan persalinan adalah segala sesuatu yang disiapkan dalam hal menyambut kelahiran anak oleh ibu hamil. Ibu nifas yang melakukan persiapan persalinan dapat dilihat dari mampunya ibu menyiapkan semua kebutuhan secara fisik, psikologis dan finansial selama kehamilan maupun proses persalinan (Nurnafisa, 2019)(Saputri, 2018)

Pada penelitian ini kelompok control mendapatkan edukasi dari buku KIA tentang persiapan persalinan yang dilakukan hanya satu kali karena kondisi social distancing. Ibu hamil diminta untuk tetap membaca perawatan kehamilan dan persiapan persalinan. Oleh sebab itu ibu hamil pada kelompok control juga mendapatkan peningkatan pengetahuan yang signifikan.

Pada kelompok intervansi kegiatan Pendidikan kehamilan dan persiapan persalinan dilakukan setiap hari dengan melakukan share materi kehamilan dan persiapan persalinan secara bertahap. Pada tahap ini ibu hamil dapat melakukan diskusi via grup sehingga ibu hamil lain dapat memberikan penyelesaian masalah kehamilan. Selain itu pada grup whatsapp ibu hamil dapat saling mensupport dalam mempersiapkan kehamilan. Komunikasi dua arah inilah yang menjadikan pengetahuan jadi lebih baik dibandingkan pada kelompok control.

Hal ini menurut teori yang kegiatan penyuluhan dapat dilakukan dengan komunikasi dua arah di mana komunikator (penyuluh) memberikan kesempatan komunikan untuk memberi feedback dari materi yang diberikan. Diskusi interaktif pada komunikasi dua arah ini diharapkan dapat memicu terjadinya perubahan perilaku yang diinginkan. Keberhasilan penyuluhan kesehatan ini tidak hanya ditentukan oleh materi yang disampaikan tetapi juga pada hubungan 
Vol 10 No 2 Juli 2021 | Page 85-94

interpersonal antar komunikator dan komunikan. Indikator keberhasilan penyuluhan yang dapat diukur secara cepat adalah adanya kesamaan arti atau pemahaman dari yang disampaikan oleh komunikator dan diterima oleh komunikan (Ira et al., 2018).

Penggunaan whatsapp group saat ini sudah lebih jauh dari kepentingan social media saja. Terdapat beberapa penelitian terkini menggunakan whatsapp group untuk keperluan pendidikan dan kesehatan. Pada artikel review menunjukkan pada 13 penelitian penggunaan media online sudah banyak dilakukan dalam dunia pendidikan dan pendidikan kesehatan. WhatsApp populer dan nyaman dalam pendidikan kedokteran. Literatur yang diterbitkan saat ini menyarankannya mungkin juga efektif sebagai alat pembelajaran medis. Dengan menggabungkan 3 strategi untuk penggunaan WhatsApp dan eksplorasi-berlakunya-penilaian kerangka desain pembelajaran terintegrasi, kami mengusulkan desain instant messenger model untuk pendidikan kedokteran. Ini mungkin menjawab kebutuhan akan desain instruksional belajar berbasis teori di media social. Namun demikian diperluka penelitian lebih lanjut akan mengklarifikasi peran WhatsApp dan model desain kami di bidang kesehatan.(Coleman \& Connor, 2019)

Grup WhatsApp dipilih sebagai alat pendukung, mengingat banyaknya variasi kelompok yang biasanya dilatih dari jarak jauh. Peneliti dapat memberikan pertanyaan dan pasien dapat bertanya dalam satu waktu dan tidak dibatasi waktu. Hasil analisis menunjukkan pengguna grup WhatsApp sebagai sosial yang menarik dukungan tambahan untuk eTools dan pembinaan pribadi kesehatan yang ada fokus yang lebih fungsional pada kemajuan individu

Didukung oleh penelitian Kholisotin et al., (2019) yang menyatakan bahwa media penyuluhan berperan penting terhadap peningkatan pengetahuan dan sumber informasi. Dengan adanya modifikasi media penyuluhan maka akan semakin meningkatkkan tingkat pengetahuan dan dapat menurunkan angka kesakitan yang ada atau dapat menurunkan angka kematian bayi yang masih tinggi. Video berbasis whatsapp ini merupakan terobosan dan inovasi baru di bidang penyuluhan kesehatan berbasis elektronik untuk mengikuti perkembangan zaman yang ada saat ini. Hasil penelitian juga menunjukkan bahwa dengan nilai signifikansi sebelum dan setelah penyuluhan sebesar $0,000<0,005$. Terdapat pengaruh penyuluhan berbasis video whatsapp tentang persalinan terhadap pengetahuan dan sikap ibu hamil trimester III di Puskesmas Klabang Kabupaten Bondowoso.

Menurut peneliti adanya Pendidikan kesehatan berbasi group whatsapp dapat sangat membantu dalam mengubah pengetahuan ibu hamil pada masa pandemic covid 19. Group whatsapp dapat melakukan share materi Pendidikan melalui video,gambar dan tulisan serta voice note. Apabila pengetahuan baik maka ibu hamil menghadapai persalinan untuk mengurangi angka kematian bayi dan proses persalinan yang aman. Pada penelitian ini, pengetahuan ibu pada kelompok intervensi mengalami peningkatan yang positif setelah dilakukan Pendidikan kesehatan yang artinya memberikan informasi melalui whatsapp group sangatlah efektif

\section{SIMPULAN}

Kesimpulan pada penelitian ini menunjukkan ada perbedaan pengetahuan ibu hamil menghadapi persalinan sebelum dan sesudah penelitian baik pada kelompok kontrol maupun perlakuan ( $\mathrm{P}$ value $<0,05$ ). Hasil juga menunjukkan bahwa nilai rata-rata peningk.atan skor pengetahuan ibu hamil menghadapi persalinan pada kelompok intervensi lebih besar dibandingkan dengan kelompol kontrol. Rata-rata peningkatan pengetahuan ibu hamil menghadapi persalinan pada kelompok kontrol dan perlakuan terdapat perbedaan yang signifikan $(\mathrm{p}$ value $<0,05$ ) 
Vol 10 No 2 Juli 2021 | Page 85-94

\section{SARAN}

Disarankan bagi tenaga kesehatan untuk memantau klien ibu hamil dengan jarak jauh seperti penggunaan grup whatsapp. Disarankan bagi ibu hamil untuk turut aktif dalam mengikuti kelompok bimbingan ibu hamil seperti dalam whatsapp group dan tetap menjalankan protocol kesehatan selama pandemic covid 19 untuk mempersiapkan persalinan yang aman. Disarankan bagi peneliti selanjutnya untuk mengembangkan aplikasi yang dapat mewadahi grup dengan jumlah lebih banyak dan dapat mengontrol variable penelitian.

\section{DAFTAR PUSTAKA}

APJII. (2017). Penetrasi \& perilaku pengguna internet indonesia 2017.

Arikunto, S. (2010). Prosedur Penelitian Suatu Pendekatan Praktik. Rineka Cipta.

Blaya, B. J. A., Fraser, H. S. F., \& Holt, B. (2010). E-Health Technologies Show Promise In Developing $\quad$ Countries. $\quad$ Policies\&potential, 242 24), https://doi.org/10.1377/hlthaff.2009.0894

Boulos, M. N. K., Giustini, D. M., \& Wheeler, S. (2016). Instagram and WhatsApp in Health and Healthcare: An Overview. Furture Internet, 8(37), 1-14. https://doi.org/10.3390/fi8030037

Chahya Kharin, H., Cukarso, S. N. A., Maulana, I. M., \& Utami, F. S. A. (2020). Dampak COVID-19 Pada Kesehatan Ibu \& Anak. Jurnal Kesehatan Metro Sai Wawai, 13(2), 76-85.

Coleman, E., \& Connor, E. O. (2019). The role of WhatsApp ${ }^{\circledR}$ in medical education; a scoping review and instructional design model. BMC Medical Education, 8(279).

Covid-, T., Shore, E. M., Bogler, T., Medicine, C., Wijayasinghe, S., Medicine, C., \& References, T. (2020). Social media use during pregnancy: A response to COVID-19 social isolation. The College of Family Physicians of Canada.

Creswell, J. (2016). Research Design Pendekatan Kualitatif, Kuantitatif dan Mixed. Pustaka Pelajar.

Gon, S., Kolkata, J., \& Rawekar, A. (2017). Effectivity of E-Learning through Whatsapp as a Teaching Learning Tool. April 2019. https://doi.org/10.18311/mvpjms/0/v0/i0/8454

Hinonaung, J. S. H., Pramardika, D. D., Wuaten, G. A., Mahihody, A. J., \& Manoppo, E. J. (2020). Tinjauan Literatur: COVID-19 Pada Ibu Hamil Jelita. Jurnal Ilmiah Kebidanan Indonesia, 11(1), $44-49$.

Hutagaol, I. O., Arini, A., \& Mujianti, C. M. (2021). Pandemic Impact of Covid 19 on Compliance of Mother for Pregnancy Reviews. Jurnal Ilmiah Kesehatan, 3(1), 200-207. https://doi.org/10.36590/jika.v3i1.125

Ira, N., Fuzie, R., Adi, N., Neka, E., Nur, L., \& Andhar, V. Y. (2018). Promosi Kesehatan. Airlangga Unerversity Press.

Irawati, H. R., Afiyanti, Y., \& Sudaryo, M. K. (2019). Effects of a support group to self efficacy of breast cancer patients that receiving chemotherapy. Jurnal Kedokteran Dan Kesehatan Indonesia, 10(3), 246-254. https://doi.org/10.20885/jkki.vol10.iss3.art7 
Vol 10 No 2 Juli 2021 | Page 85-94

KEMENKES. (2020). Pedoman Bagi Ibu Hamil, Ibu Nifas, dan Bayi Baru Lahir Di Era Pandemi Covid-19. KEMENTERIAN KESEHATAN RI.

Kemenkes RI. (2020). Covid 19 Indonesia.

Kholisotin, K., Agustin, Y. D., \& Prasetyo, A. D. (2019). Pengaruh Penyuluhan Berbasis Video Whatsapp tentang Persalinan Terhadap Pengetahuan dan Sikap Ibu Hamil Trimester III di Puskesmas Klabang Kabupaten Bondowoso. THE INDONESIAN JOURNAL OF HEALTH SCIENCE, 11(02), 1-9. https://doi.org/10.38040/js.v11i02.32

King, T. L., Brucker, M. C., Osborne, K., \& Jevitt, C. (2019). Varney's Midwifery. World Headquarters Jones \& Bartlett Learning.

Liu, H., Wang, L. L., Zhao, S. J., Kwak-Kim, J., Mor, G., \& Liao, A. H. (2020). Why are pregnant women susceptible to COVID-19? An immunological viewpoint. Journal of Reproductive Immunology, 139(March), 103122. https://doi.org/10.1016/j.jri.2020.103122

Lucia, S., Purwandari, A., \& Pesak, E. (2013). Pengaruh Pelaksanaan Kelas Ibu Hamil Terhadap Pengetahuan Tentang Persiapan Persalinan. Jurnal Ilmiah Bidan, 30(1), 61-65.

Muktashim, A. (2018). Pengembangan Aplikasi Kartu menuju Sehat Berbasis Android menggunakan metode extreme programming. UIN Sunan Kalijaga.

Notoatmodjo, S. (2015). Ilmu Perilaku Kesehatan. Rineka Cipta.

Nurnafisa, S. (2019). The Asian Parent Indonesia.

Saputri, N. (2018). Pengaruh Massase Effleurage Terhadap Pengurangan Nyeri Persalinan Kala I Fase Aktif di Puskesmas Way Jepara Lampung Timur 2017. Prosiding Book, 65.

Simons, L. P. A. (2018). eHealth WhatsApp Group for Social Support : Preliminary Results. BLED Proceedings, 1-15.

Sulistyawati, A., \& Nugraheny, E. (2013). Asuhan Kebidanan Pada Ibu Bersalin. Salemba Medika.

Sutrisna, I. P. G. (2020). Gerakan Literasi Digital Pada Masa Pandemi Covid-19. Stilistika: Jurnal Pendidikan Bahasa Dan Seni, 8, 268-283. https://doi.org/10.5281/zenodo.3884420

Wenerda, I. (2019). Grup WhatsApp Sebagai Wadah Komunikasi Ibu-Ibu di Era Digital. Jurnal Penelitian Pers Dan Komunikasi Pembangunan, 23(1), 43-53. https://doi.org/10.46426/jp2kp.v23i1.105 